\title{
MENDUDUKKAN KASULTANAN DAN KADIPATEN SEBAGAI SUBYEK HAK MILIK ATAS TANAH KASULTANAN DAN TANAH KADIPATEN DALAM KEISTIMEWAAN YOGYAKARTA
}

\author{
(Provide the Kasultanan and the Kadipaten as Subject of Property Rights toward the Land of \\ Kasultanan and Kadipaten in the Privilege of Yogyakarta)
}

\author{
Dian Agung Wicaksono \\ Departemen Hukum Tata Negara Fakultas Hukum Universitas Gadjah Mada \\ Jl. Sosio Yustisia No. 1 Bulaksumur, Sleman, D.I. Yogyakarta \\ Email: dianagung@ugm.ac.id \\ Ananda Prima Yurista \\ Departemen Hukum Agraria Fakultas Hukum Universitas Gadjah Mada \\ JI. Sosio Yustisia No. 1 Bulaksumur, Sleman, D.I. Yogyakarta \\ Email: aprimayurista@gmail.com \\ Almonika Cindy Fatika Sari \\ Pusat Kajian Hukum Adat Djojodigoeno Fakultas Hukum Universitas Gadjah Mada \\ JI. Sosio Yustisia No. 1 Bulaksumur, Sleman, D.I. Yogyakarta \\ Email: almonika.cindy.f@mail.ugm.ac.id
}

Naskah diterima: 23 Agustus 2019; revisi: 9 Oktober 2019; disetujui: 8 November 2019

\begin{abstract}
Abstrak
Undang-Undang Nomor 13 Tahun 2012 tentang Keistimewaan Daerah Istimewa Yogyakarta (UU KDIY) menetapkan Kasultanan dan Kadipaten sebagai badan hukum pemegang hak milik atas tanah Kasultanan dan tanah Kadipaten. Penetapan tersebut menjadi diskursus dalam konteks hukum pertanahan di Indonesia, karena badan hukum yang diperkenankan menjadi pemegang hak milik atas tanah secara definitif disebutkan dalam Peraturan Pemerintah Nomor 38 Tahun 1963 tentang Penunjukan Badan-Badan Hukum yang Dapat Mempunyai Hak Milik atas Tanah (PP 38/1963). Pengaturan dalam PP a quo menimbulkan persepsi seolah-olah Kasultanan dan Kadipaten tidak dapat menjadi pemegang hak milik atas tanah Kasultanan dan tanah Kadipaten. Penelitian ini mencoba melihat dari perspektif kajian hukum pemerintahan daerah dan hukum agraria dalam kerangka menjernihkan kedudukan hukum Kasultanan dan Kadipaten sebagai pemegang hak milik atas tanah Kasultanan dan tanah Kadipaten. Penelitian ini menggunakan metode yuridis normatif, dengan menganalisis data sekunder berupa peraturan perundang-undangan dan pustaka yang terkait dengan keistimewaan Yogyakarta dan hukum pertanahan di Indonesia. Hasil dari penelitian ini menunjukkan bahwa Kasultanan dan Kadipaten merupakan salah satu badan hukum khusus yang terlepas dari ketentuan-ketentuan yang melekat bagi badan hukum publik atau privat secara an sich.

Kata Kunci: Kasultanan, Kadipaten, tanah, hak milik, keistimewaan, Yogyakarta
\end{abstract}

\begin{abstract}
Law No. 13 of 2012 concerning the Privileges of the Special Region of Yogyakarta stipulates that the Kasultanan and the Kadipaten in as legal entities that hold ownership rights over the land of Kasultanan and the land of Kadipaten. The stipulation becomes a discourse in the context of land law in Indonesia, because legal entities that are permitted to become holders of land rights are definitively mentioned in Government Regulation No. 38 of 1963 concerning the Appointment of Legal Entities that Can Have Property Rights over Land. The regulation gives rise to the perception as if the Kasultanan and the Kadipaten cannot become holders of ownership rights on the land of Kasultanan and the land of Kadipaten. This research tries to analyse from the perspective of local government law and agrarian law in the framework of clarifying the legal position of the Kasultanan and the Kadipaten as holders of ownership rights on the land of Kasultanan and the land of Kadipaten. This research uses the normative-legal method, by analyzing secondary data in the form of laws and references related to the privileges of Yogyakarta and land law in Indonesia. The results indicate that the Kasultanan and the Kadipaten are one of the special legal entities that are independent of the provisions attached to public or private legal entities.
\end{abstract}

Keywords: Kasultanan, Kadipaten, land, property rights, privilege, Yogyakarta 


\section{A. Pendahuluan}

Indonesia berkomitmen untuk mengakui dan menghormati satuan-satuan pemerintahan daerah yang bersifat khusus atau bersifat istimewa yang diatur Pasal 18B ayat (1) Undang-Undang Dasar Negara Republik Indonesia Tahun 1945. Berdasarkan Pasal a quo, terdapat beberapa daerah yang berstatus sebagai daerah khusus atau istimewa, yaitu Provinsi Daerah Istimewa Yogyakarta ${ }^{1}$, Provinsi Daerah Khusus Ibukota Jakarta ${ }^{2}$, Provinsi Aceh ${ }^{3}$, Provinsi Papua ${ }^{4}$, dan Provinsi Papua Barat ${ }^{5}$.

Daerah Istimewa Yogyakarta menjadi salah satu contoh daerah yang status keistimewaannya secara rinci dan rigid dilekatkan sebagai top-up urusan pemerintahan yang pada Pemerintah Provinsi, yang dalam Undang-Undang Nomor 13 Tahun 2012 tentang Keistimewaan Daerah Istimewa Yogyakarta (UU KDIY) disebut sebagai urusan keistimewaan, yaitu: (a) tata cara pengisian jabatan, kedudukan, tugas, dan wewenang Gubernur dan Wakil Gubernur; (b) kelembagaan Pemerintah Daerah DIY; (c) kebudayaan; (d) pertanahan; dan (e) tata ruang. ${ }^{6}$ Status keistimewaan DIY tidak dapat dilepaskan dari peran Sri Sultan Hamengku
Buwono IX (penguasa Kasultanan Yogyakarta) dan KGPAA Paku Alam VIII (penguasa Kadipaten Paku Alam) dalam perjalanan historis Republik Indonesia. ${ }^{7}$

Spesifik dalam penyelenggaraan kewenangan pertanahan, Kasultanan dan Kadipaten dalam UU KDIY dinyatakan sebagai badan hukum yang merupakan subjek hak yang mempunyai hak milik atas tanah Kasultanan dan tanah Kadipaten, berupa tanah keprabon dan tanah bukan keprabon yang terdapat di seluruh kabupaten/ kota dalam wilayah DIY. ${ }^{8}$ Kasultanan dan Kadipaten berwenang mengelola dan memanfaatkan tanah Kasultanan dan tanah Kadipaten ditujukan untuk sebesar-besarnya pengembangan kebudayaan, kepentingan sosial, dan kesejahteraan masyarakat. ${ }^{9}$

Penetapan Kasultanan dan Kadipaten sebagai badan hukum pemegang hak milik atas tanah Kasultanan dan tanah Kadipaten menjadi diskursus dalam konteks hukum pertanahan di Indonesia. Hal ini mengingat dalam hukum pertanahan, badan hukum yang diperkenankan menjadi pemegang hak milik atas tanah secara definitif disebutkan dalam Peraturan Pemerintah Nomor 38 Tahun 1963 tentang Penunjukan Badan- 
Badan Hukum yang Dapat Mempunyai Hak Milik atas Tanah (PP 38/1963). Pengaturan dalam PP a quo menimbulkan persepsi seolah-olah Kasultanan dan Kadipaten tidak dapat menjadi pemegang hak milik atas tanah Kasultanan dan tanah Kadipaten. Persepsi tersebut menjadi semakin rumit karena dalam UU KDIY diatur bahwa hak milik atas tanah Kasultanan dan tanah Kadipaten didaftarkan pada lembaga pertanahan dan pendaftaran dilakukan sesuai dengan ketentuan peraturan perundang-undangan. ${ }^{10}$

Berdasarkan latar belakang tersebut, penelitian ini berfokus pada permasalahan: (a) bagaimana konstruksi hukum hak milik atas tanah dalam sistem hukum Indonesia? (b) bagaimana kedudukan hukum Kasultanan dan Kadipaten dalam konteks keistimewaan Yogyakarta? (c) Bagaimana kedudukan hukum Kasultanan dan Kadipaten sebagai subyek hak milik atas tanah Kasultanan dan tanah Kadipaten?

\section{B. Metode Penelitian}

Penelitian ini merupakan penelitian yuridis normatif, ${ }^{11}$ dengan menggunakan bahan pustaka, yang terdiri dari 2 (dua) bahan hukum yaitu: (1) bahan hukum primer yang terdiri dari norma dasar atau kaidah, ketentuan atau peraturan dasar, serta peraturan perundangundangan; dan (2) bahan hukum sekunder adalah bahan hukum yang memberikan penjelasan lebih lanjut dari bahan hukum primer berupa literatur, artikel jurnal, dan juga hasil penelitian yang relevan. ${ }^{12}$ Pengambilan data dilakukan dengan studi pustaka terhadap buku, artikel, hasil penelitian, dan peraturan perundang-undangan yang relevan. Analisis data dilakukan secara deskriptif kualitatif untuk menjawab rumusan masalah dalam penelitian ini.

\section{Pembahasan}

\section{Konstruksi Hukum Hak Milik atas Tanah dalam Sistem Hukum Indonesia}

Sebelum masuk dalam pembahasan, Penulis bermaksud memberikan kejelasan bahwa yang dimaksud dengan konstruksi hukum dimaknai sebagai "susunan dan hubungan"13 mengenai hak milik atas tanah dalam sistem hukum Indonesia, yang mana hal ini berbeda dengan konstruksi hukum dalam ranah teori penemuan hukum, yang memaknai konstruksi hukum sebagai metode penemuan hukum dalam hal peraturannya memang tidak ada. ${ }^{14}$ Dengan demikian, penggunaan diksi konstruksi dalam pembahasan ini berfokus pada susunan dan hubungan hak milik atas tanah dalam sistem hukum Indonesia. Konstruksi hukum hak milik atas tanah dalam sistem hukum Indonesia setidaknya dapat ditelusuri dalam beberapa pengaturan berikut:

10 Pasal 33 ayat (1) dan (2) Undang-Undang Nomor 13 Tahun 2012 tentang Keistimewaan Daerah Istimewa Yogyakarta.

11 Soedjono Soekanto dan Sri Mamudji, Penelitian Hukum Normatif: Suatu Tinjauan Singkat, (Jakarta: Raja Grafindo Persada, 1994), hlm. 13.

12 Soerdjono Soekanto, Pengantar Penelitian Hukum, (Jakarta: UI Press, 1986), hlm. 132.

13 Kamus Besar Bahasa Indonesia, "konstruksi", https://kbbi.kemdikbud.go.id/entri/konstruksi, (diakses 23 Agustus 2019).

14 Lebih lanjut lihat Jazim Hamidi, Hermeneutika Hukum (Sejarah, Filsafat \& Metode Tafsir) Edisi Revisi, (Malang: UB Press, 2014). 
Pengaturan Pertama, Undang-Undang Nomor 5 Tahun 1960 tentang Peraturan Dasar Pokok-Pokok Agraria (UUPA). Membahas konstruksi hukum hak milik atas tanah tidak dapat dilepaskan dari pengaturan dalam UUPA. Hak milik adalah hak turun temurun, terkuat dan terpenuh yang dapat dipunyai orang atas tanah. ${ }^{15}$ Hak milik dapat beralih dan dialihkan kepada pihak lain. ${ }^{16}$ UUPA juga menegaskan bahwa hanya warga negara Indonesia yang dapat mempunyai hak milik. ${ }^{17}$ Selain WNI, Pemerintah juga menetapkan badan-badan hukum yang dapat mempunyai hak milik dan syarat-syaratnya. ${ }^{18}$ Adapun orang asing yang sesudah berlakunya UUPA memperoleh hak milik karena pewarisan tanpa wasiat atau percampuran harta karena perkawinan, demikian pula warga negara Indonesia yang mempunyai hak milik dan setelah berlakunya UUPA dan kehilangan kewarganegaraannya wajib melepaskan hak milik atas tanah di dalam jangka waktu satu tahun sejak diperolehnya hak tersebut atau hilangnya kewarganegaraan itu, yang mana jika sesudah jangka waktu tersebut lampau hak milik itu dilepaskan, maka hak tersebut hapus karena hukum dan tanahnya jatuh pada Negara, dengan ketentuan bahwa hakhak pihak lain yang membebaninya tetap berlangsung. ${ }^{19}$

Lebih lanjut, hak milik, demikian pula setiap peralihan, hapusnya dan pembebannya dengan hak-hak lain harus didaftarkan. ${ }^{20}$ Hak milik juga dapat dijadikan jaminan utang dengan dibebani hak tanggungan. ${ }^{21}$ Hak milik dapat hapus bila: (a) tanahnya jatuh kepada negara: (1) karena pencabutan hak; (2) karena penyerahan dengan sukarela oleh pemiliknya; (3) karena ditelantarkan; atau (4) karena ketentuan Pasal 21 ayat (3) dan 26 ayat (2) UUPA; atau (b) tanahnya musnah. ${ }^{22}$

UUPA juga mengatur ketentuan konversi untuk hak-hak atas tanah yang memberi wewenang sebagaimana atau mirip dengan hak yang dimaksud dalam Pasal 20 ayat (1) UUPA seperti yang disebut dengan nama lain, yang ada ketika mulai berlakunya UUPA, yaitu hak agrarisch eigendom, milik, yasan, andarbeni, hak atas druwe, hak atas druwe desa, pesini, grand Sultan, landerinjbezitrecht, altijddurende erfpacht, hak usaha atas bekas tanah partikelir dan hak-hak lain dengan nama apapun juga yang akan ditegaskan lebih lanjut oleh Menteri Agraria, sejak mulai berlakunya UUPA menjadi hak milik tersebut dalam Pasal 20 ayat (1) UUPA, kecuali jika yang mempunyainya tidak memenuhi syarat sebagai yang tersebut dalam Pasal 21 UUPA. ${ }^{23}$

Berdasarkan uraian di atas, yang menjadi titik tekan adalah: Pertama, selama UndangUndang mengenai hak milik belum terbentuk, maka yang berlaku adalah ketentuanketentuan hukum adat setempat dan peraturan-peraturan lainnya mengenai hak-

15 Pasal 20 ayat (1) Undang-Undang Nomor 5 Tahun 1960 tentang Peraturan Dasar Pokok-Pokok Agraria.

16 Pasal 20 ayat (2) Undang-Undang Nomor 5 Tahun 1960 tentang Peraturan Dasar Pokok-Pokok Agraria.

17 Pasal 21 ayat (1) Undang-Undang Nomor 5 Tahun 1960 tentang Peraturan Dasar Pokok-Pokok Agraria.

18 Pasal 21 ayat (2) Undang-Undang Nomor 5 Tahun 1960 tentang Peraturan Dasar Pokok-Pokok Agraria.

19 Pasal 21 ayat (3) Undang-Undang Nomor 5 Tahun 1960 tentang Peraturan Dasar Pokok-Pokok Agraria.

20 Pasal 32 ayat (1) Undang-Undang Nomor 5 Tahun 1960 tentang Peraturan Dasar Pokok-Pokok Agraria.

21 Pasal 33 Undang-Undang Nomor 5 Tahun 1960 tentang Peraturan Dasar Pokok-Pokok Agraria.

22 Pasal 34 Undang-Undang Nomor 5 Tahun 1960 tentang Peraturan Dasar Pokok-Pokok Agraria.

23 Ketentuan Konversi Pasal II ayat (1) Undang-Undang Nomor 5 Tahun 1960 tentang Peraturan Dasar PokokPokok Agraria. 
hak atas tanah yang memberi wewenang sebagaimana atau mirip dengan yang dimaksud dalam Pasal 20 UUPA (perihal hak milik), sepanjang tidak bertentangan dengan jiwa dan ketentuan-ketentuan UUPA. Kedua, hak-hak atas tanah yang memberi wewenang sebagaimana atau mirip dengan hak milik seperti, yang ada pada mulai berlakunya UUPA, seperti hak agrarisch eigendom, milik, yasan, andarbeni, hak atas druwe, hak atas druwe desa, pesini, grand Sultan, landerinjbezitrecht, altijddurende erfpacht, hak usaha atas bekas tanah partikelir dan hakhak lain dengan nama apapun juga yang akan ditegaskan lebih lanjut oleh Menteri Agraria, sejak mulai berlakunya UUPA menjadi hak milik sebagaimana diatur dalam Pasal 20 ayat (1) UUPA.

Pengaturan Kedua, Peraturan Pemerintah Nomor 38 Tahun 1963 tentang Penunjukan Badan-Badan Hukum yang Dapat Mempunyai Hak Milik atas Tanah (PP 38/1963). PP a quo merupakan peraturan lebih lanjut mengenai badan hukum sebagai penyandang subjek hak milik atas tanah sebagaimana dimandatkan oleh UUPA. Menurut PP 38/1963, badanbadan hukum yang dapat mempunyai hak milik atas tanah, antara lain: (a) Bank-bank yang didirikan oleh Negara (selanjutnya disebut Bank Negara); (b) Perkumpulan-perkumpulan Koperasi Pertanian yang didirikan berdasar atas Undang-Undang Nomor 79 Tahun 1958 (Lembaran-Negara Tahun 1958 Nomor 139);

(c) Badan-badan keagamaan, yang ditunjuk oleh Menteri Pertanian/Agraria, setelah mendengar Menteri Agama; (d) Badan-badan sosial, yang ditunjuk oleh Menteri Pertanian/ Agraria, setelah mendengar Menteri Kesejahteraan Sosial. ${ }^{24}$

PP 38/1963 juga memandatkan bahwa Menteri Pertanian/Agraria berwenang untuk meminta kepada badan-badan hukum, agar supaya mengalihkan tanah-tanah milik yang dipunyainya pada waktu mulai berlakunya PP 38/1963 kepada pihak lain yang dapat mempunyai hak milik atau memintanya untuk diubah menjadi hak guna bangunan, hak guna usaha atau hak pakai jika berlangsungnya pemilikan itu bertentangan dengan ketentuan Pasal 2, 3, dan 4 sebagaimana diatur dalam PP 38/1963. ${ }^{25}$ Berdasarkan uraian di atas, yang menjadi titik tekan adalah bahwa terdapat badan-badan hukum yang ditunjuk oleh Pemerintah untuk dapat mempunyai hak milik.

Pengaturan Ketiga, Peraturan Pemerintah Nomor 40 Tahun 1996 tentang Hak Guna Usaha, Hak Guna Bangunan, dan Hak Pakai (PP 40/1996). PP a quo merupakan peraturan lebih lanjut mengenai ketentuan Hak Guna Usaha (HGU), Hak Guna Bangunan (HGB) dan Hak Pakai (HP) sebagaimana diatur dalam UUPA. Apa kaitannya HGU, HGB, dan HP dalam konstruksi hukum hak milik atas tanah? Jika mencermati pengaturan dalam PP 40/1996 yang berkaitan dengan hak milik atas tanah adalah pengaturan mengenai HGB dan HP. PP 40/1996 mengatur bahwa tanah hak milik merupakan salah satu tanah yang dapat diberikan dengan HGB atau HP. ${ }^{26}$

24 Pasal 1 Peraturan Pemerintah Nomor 38 Tahun 1963 tentang Penunjukan Badan-Badan Hukum yang Dapat Mempunyai Hak Milik atas Tanah.

25 Pasal 6 Peraturan Pemerintah Nomor 38 Tahun 1963 tentang Penunjukan Badan-Badan Hukum yang Dapat Mempunyai Hak Milik atas Tanah.

26 Pasal 21 jo. Pasal 41 Peraturan Pemerintah Nomor 40 Tahun 1996 tentang Hak Guna Usaha, Hak Guna Bangunan, dan Hak Pakai. 
Pemberian HGB atau HP di atas tanah Hak Milik terjadi dengan adanya akta yang dibuat PPAT, yang mana pemberian hak tersebut wajib didaftarkan pada Kantor Pertanahan. ${ }^{27}$ Pendaftaran tanah tersebut mengikat pihak ketiga.

HGB di atas tanah Hak Milik diberikan dalam jangka waktu 30 (tiga puluh) tahun, yang mana HGB dapat diperbaharui atas kesepakatan antara pemegang HGB dengan pemegang Hak Milik. ${ }^{28}$ Pemberian HGB baru dengan akta yang dibuat oleh PPAT dan hak tersebut wajib didaftarkan. Sementara, jangka waktu HP di atas tanah Hak Milik adalah 20 (dua puluh) tahun dan tidak dapat diperpanjang. ${ }^{29}$ Namun, HP di atas tanah Hak Milik dapat diperbaharui atas kesepakatan antara antar pemegang HP dengan pemegang Hak Milik dengan pemberian HP baru berdasarkan akta yang dibuat oleh PPAT dan hak tersebut wajib didaftarkan. ${ }^{30}$

HGB di atas tanah Hak Milik dapat beralih dan dialihkan kepada pihak lain dengan persetujuan tertulis dari pemegang Hak Milik yang bersangkutan, ${ }^{31}$ sedangkan HP di atas tanah Hak Milik hanya dapat dialihkan apabila hal tersebut dimungkinkan dalam perjanjian pemberian HP di atas tanah Hak Milik yang bersangkutan dan harus dilakukan dengan persetujuan tertulis dari pemegang Hak Milik. ${ }^{32}$

Peralihan yang dimaksud oleh PP 40/1996 ini adalah jual beli, tukar menukar, penyertaan modal, hibah, atau pewarisan. ${ }^{33}$ Pemegang Hak Milik sebelum jangka waktu berakhir dapat membatalkan HGB apabila pemegang HGB tidak memenuhi syarat-syarat atau kewajiban-kewajiban yang tertuang dalam perjanjian pemberian HGB antara pemegang HGB dan pemegang Hak Milik. ${ }^{34}$ Hapusnya HGB atas tanah Hak Milik tersebut mengakibatkan tanahnya kembali ke dalam penguasaan pemegang Hak Milik. ${ }^{35}$ Pemegang Hak Milik dapat membatalkan HP di atas tanah Hak Milik apabila tidak dipenuhinya syarat-syarat atau kewajiban-kewajiban yang tertuang dalam perjanjian pemberian HP antara pemegang HP dan pemegang Hak Milik. ${ }^{36}$ Hapusnya Hak Pakai atas tanah Hak Milik tersebut mengakibatkan tanahnya

27 Pasal 24 ayat (1) jo. Pasal 44 ayat (1) Peraturan Pemerintah Nomor 40 Tahun 1996 tentang Hak Guna Usaha, Hak Guna Bangunan, dan Hak Pakai.

28 Pasal 29 ayat (1) dan ayat (2) Peraturan Pemerintah Nomor 40 Tahun 1996 tentang Hak Guna Usaha, Hak Guna Bangunan, dan Hak Pakai.

29 Pasal 49 ayat (1) Peraturan Pemerintah Nomor 40 Tahun 1996 tentang Hak Guna Usaha, Hak Guna Bangunan, dan Hak Pakai.

30 Pasal 49 ayat (2) Peraturan Pemerintah Nomor 40 Tahun 1996 tentang Hak Guna Usaha, Hak Guna Bangunan, dan Hak Pakai.

31 Pasal 34 ayat (1) dan ayat (8) Peraturan Pemerintah Nomor 40 Tahun 1996 tentang Hak Guna Usaha, Hak Guna Bangunan, dan Hak Pakai.

32 Pasal 54 ayat (2) dan ayat (9) Peraturan Pemerintah Nomor 40 Tahun 1996 tentang Hak Guna Usaha, Hak Guna Bangunan, dan Hak Pakai.

33 Pasal 34 ayat (2) Peraturan Pemerintah Nomor 40 Tahun 1996 tentang Hak Guna Usaha, Hak Guna Bangunan, dan Hak Pakai.

34 Pasal 35 ayat (1) huruf b angka 2 Peraturan Pemerintah Nomor 40 Tahun 1996 tentang Hak Guna Usaha, Hak Guna Bangunan, dan Hak Pakai.

35 Pasal 36 ayat (3) Peraturan Pemerintah Nomor 40 Tahun 1996 tentang Hak Guna Usaha, Hak Guna Bangunan, dan Hak Pakai.

36 Pasal 55 ayat (2) huruf b angka 2 Peraturan Pemerintah Nomor 40 Tahun 1996 tentang Hak Guna Usaha, Hak Guna Bangunan, dan Hak Pakai. 
kembali dalam penguasaan pemegang Hak Milik. $^{37}$

Berdasarkan uraian di atas, yang menjadi titik tekan adalah: Pertama, pemegang Hak Milik dapat memberikan HGB atau HP di atas tanah Hak Miliknya berdasarkan akta yang dibuat oleh PPAT dan pemberian hak tersebut wajib didaftarkan kepada Kantor Pertanahan. Kedua, pemberian HGB atau HP didasarkan perjanjian pemberian HGB atau HP antara pemegang $\mathrm{HGB}$ atau HP dengan pemegang Hak Milik. Ketiga, HGB atau HP di atas tanah Hak Milik diberikan dalam jangka waktu tertentu dan dapat diperbaharui dengan kesepakatan antara pemegang HGB atau HP dengan pemegang Hak Milik. Keempat, apabila pemegang HGB atau HP bermaksud mengalihkan haknya, maka hal tersebut harus dilakukan dengan persetujuan tertulis dari pemegang Hak Milik. Kelima, pemegang Hak Milik dapat membatalkan HGB atau HP apabila pemegang HGB atau HP tidak memenuhi syarat atau ketentuan dalam perjanjian pemberian HGB dan HP di atas tanah Hak Milik. Keenam, apabila HGB atau HP hapus maka penguasaan kembali pada pemegang Hak Milik.

\section{Pengaturan Keempat, Peraturan} Pemerintah Nomor 24 Tahun 1997 tentang Pendaftaran Tanah (PP 24/1997). Peraturan Pemerintah ini mengatur bahwa salah satu obyek pendaftaran tanah adalah bidangbidang tanah yang dipunyai dengan Hak Milik, Hak Guna Usaha, Hak Guna Bangunan dan Hak Pakai. ${ }^{38}$ Dengan demikian, pemegang Hak Milik ataupun Hak Guna Usaha, Hak Guna
Bangunan di atas tanah Hak Milik dan juga Hak Pakai di atas tanah Hak Milik wajib melakukan pendaftaran tanah sebagaimana diatur dalam PP a quo.

\section{Kedudukan Hukum Kasultanan dan Kadipaten dalam Konteks Keistimewaan Yogyakarta}

Kedudukan Hukum Kasultanan dan Kadipaten dalam konteks keistimewaan tidak dapat dilepaskan dari perjalanan historis Bangsa Indonesia dalam merebut dan mempertahankan kemerdekaan Indonesia. Pada tanggal 18 Agustus 1945, Sultan Hamengku Buwono IX dan Paku Alam VIII mengirimkan kawat ucapan selamat kepada Soekarno dan Moh. Hatta selaku Presiden dan Wakil Presiden Negara Republik Indonesia. ${ }^{39}$ Merespons ucapan tersebut, Soekarno selaku Presiden mengeluarkan Piagam Penetapan yang ditujukan masing-masing kepada Sultan Hamengku Buwono IX dan Paku Alam VIII, sebagai berikut: ${ }^{40}$

\footnotetext{
37 Pasal 56 ayat (3) Peraturan Pemerintah Nomor 40 Tahun 1996 tentang Hak Guna Usaha, Hak Guna Bangunan, dan Hak Pakai.

38 Pasal 19 ayat (1) huruf a Peraturan Pemerintah Nomor 24 Tahun 1997 tentang Pendaftaran Tanah.

39 Abdur Rozaki, et al., Membongkar Mitos Keistimewaan Yogyakarta (Yogyakarta: IRE Press, 2003), hlm. 18.

40 Piagam Penetapan Sultan Hamengku Buwono IX dan Paku Alam VIII dari Presiden Republik Indonesia.
} 
Tabel 1. Piagam Penetapan dari Presiden Republik Indonesia

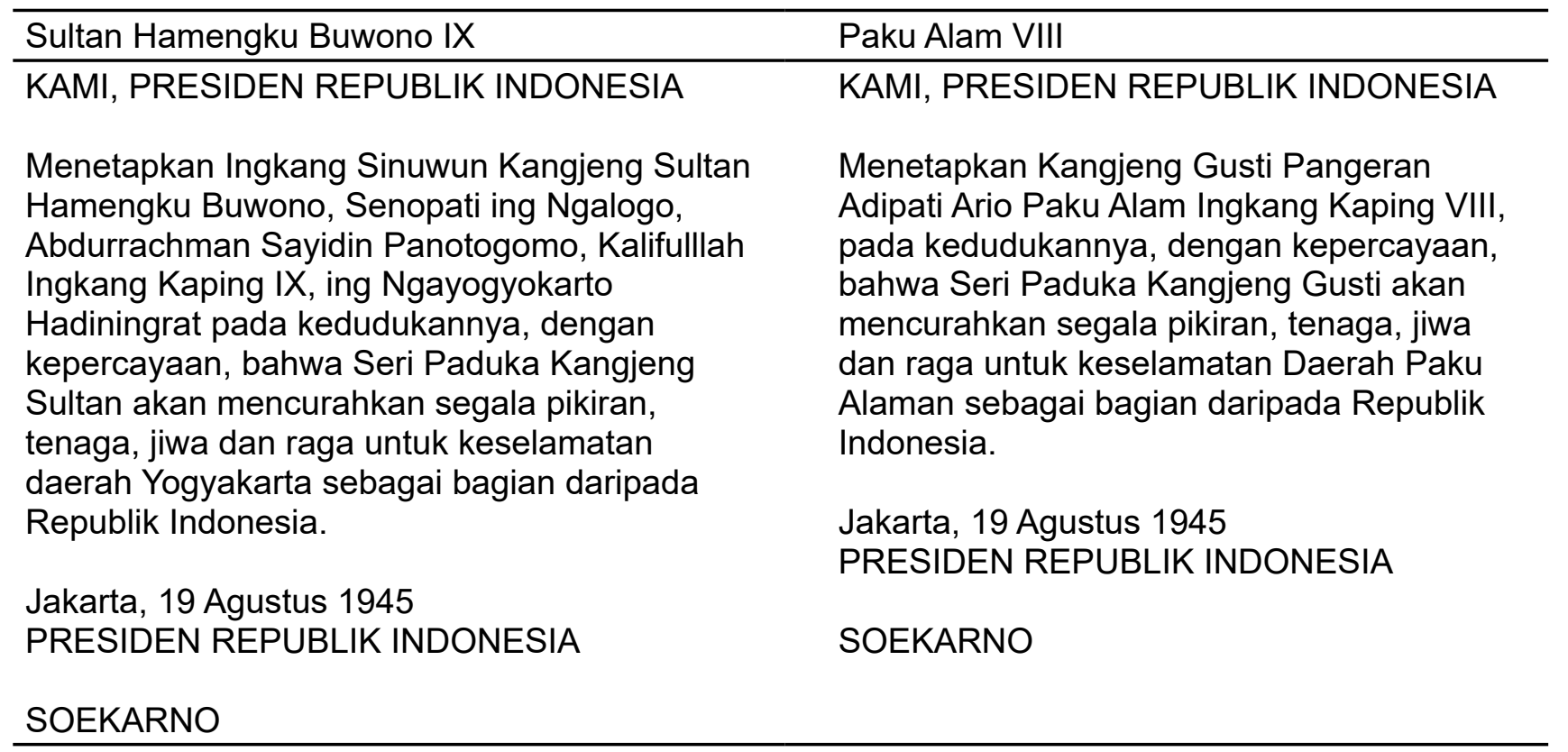

Sumber: Diolah Penulis, 2019.

Piagam tersebut dibuat pada tanggal 19 Agustus 1945, namun baru diserahkan pada tanggal 6 September 1945, setelah mengetahui sikap resmi Kasultanan Yogyakarta dan Kadipaten Paku Alaman terhadap Proklamasi Kemerdekaan Republik Indonesia. Lalu, Sultan Hamengku Buwono IX dan Paku Alam VIII menerbitkan amanat, yang kemudian dikenal dengan Maklumat 5 September 1945, yang berisi:

Tabel 2. Amanat Sultan Hamengku Buwono IX dan Paku Alam VIII

\begin{tabular}{|c|c|}
\hline Isi Maklumat ${ }^{41}$ & Isi Maklumat ${ }^{42}$ \\
\hline AMANAT & AMANAT \\
\hline SRI PADUKA INGKENG SINUWUN KANGDJENG & SRI PADUKA KANGDJENG GUSTI PANGERAN ADIPATI \\
\hline SULTAN: & ARIO PAKU ALAM \\
\hline $\begin{array}{l}\text { Kami Hamengku Buwono IX, Sultan Negeri } \\
\text { Ngajogjakarta Hadiningrat menjatakan: }\end{array}$ & $\begin{array}{l}\text { Kami Paku Alam VIII Kepala Negeri Paku Alaman, } \\
\text { Negeri Ngajogjakarto Hadiningrat menjatakan: }\end{array}$ \\
\hline $\begin{array}{l}\text { 1. Bahwa Negeri Ngajogjakarto Hadiningrat jang } \\
\text { bersifat Keradjaan adalah Daerah Istimewa dari } \\
\text { Negara Republik Indonesia. }\end{array}$ & $\begin{array}{l}\text { 1. Bahwa Negeri Paku Alaman jang bersifat } \\
\text { keradjaan adalah daerah istimewa dari Negara } \\
\text { Republik Indonesia. }\end{array}$ \\
\hline $\begin{array}{l}\text { 2. Bahwa Kami sebagai Kepala Daerah memegang } \\
\text { segala kekuasaan dalam Negeri Ngajogjakarta } \\
\text { Hadiningrat, dan oleh karena itu berhubung } \\
\text { dengan keadaan pada dewasa ini segala urusan } \\
\text { pemerintahan dalam Negeri Ngajogjakarta }\end{array}$ & $\begin{array}{l}\text { 2. Bahwa kami sebagai Kepala Daerah memegang } \\
\text { segala kekuasaan dalam Negeri Paku Alaman, } \\
\text { dan oleh karena itu berhubung dengan keadaan } \\
\text { pada dewasa ini segala urusan pemerintahan } \\
\text { dalam Negeri Paku Alaman mulai saat ini berada }\end{array}$ \\
\hline
\end{tabular}

41 Berita Republik Indonesia Tahun II Nomor 4-5.

42 Berita Republik Indonesia Tahun II Nomor 6. 
Hadiningrat mulai saat ini berada di tangan Kami dan kekuasaan-kekuasaan lainnja Kami pegang seluruhnja.

3. Bahwa perhubungan antara Negeri Ngajogjakarta Hadiningrat dengan Pemerintah Pusat Negara Republik Indonesia, bersifat langsung dan Kami bertanggung djawab atas Negeri Kami langsung kepada Presiden Republik Indonesia.

Kami memerintahkan supaja segenap penduduk dalam Negeri Ngajogjakarta Hadiningrat mengindahkan Amanat Kami ini.

Ngajogjokarto Hadiningrat, 28 Puasa Ehe 1876 (5-91945)

HAMENGKU BUWONO di tangan Kami dan kekuasaan-kekuasaan lainnja Kami pegang seluruhnja.

3. Bahwa perhubungan antara Negeri Paku Alaman dengan Pemerintah Pusat Negara Republik Indonesia, bersifat langsung dan Kami bertanggung djawab atas Negeri Kami langsung kepada Presiden Republik Indonesia.

Kami memerintahkan supaja segenap penduduk dalam Negeri Paku Alaman mengindahkan Amanat Kami ini.

Paku Alaman, 28 Puasa

Ehe 1876 (5-9-1945)

PAKU ALAM

Sumber: Diolah Penulis, 2019.

Melalui Maklumat 5 September 1945 yang dikeluarkan oleh Sultan Hamengku Buwono IX dan Paku Alam VIII, melahirkan status "keistimewaan" kepada Yogyakarta. Dalam Maklumat tersebut, Kasultanan dan Kadipaten menyatakan secara tegas bergabung dengan Republik Indonesia sebagai daerah istimewa. Ditegaskan pula dalam Maklumat tersebut bahwa Sultan Hamengku Buwono IX dan Paku Alam VIII berhubungan langsung dengan Pemerintah Pusat dan bertanggung jawab langsung kepada Presiden. Konsekuensi dari Maklumat tersebut, kekuasaan yang semula berada di tangan tentara Jepang beralih ke tangan Republik Indonesia, khusus di Kasultanan dan Kadipaten dijalankan oleh Sultan Hamengku Buwono IX dan Paku Alam VIII. ${ }^{43}$ Meskipun pada waktu itu dalam kenyataannya tentara Jepang masih berada di wilayah Kasultanan dan Kadipaten dengan tegas tidak lagi mengakui kekuasaan Jepang. ${ }^{44}$

Lebih lanjut Sultan Hamengku Buwono IX dan Paku Alam VIII mengeluarkan kesepakatan bersama pada tanggal 30 Oktober 1945 yang menegaskan sifat keistimewaan daerahnya, yaitu: (a) penguasa Kasultanan dan Paku Alaman menjadi kepala daerah dalam arti sebagai gubernur dan wakil gubernur, serta bertanggung jawab langsung kepada Presiden; dan (b) akan segera dibentuk badan legislatif yang disebut Komite Nasional Indonesia (KNI) Yogyakarta yang bertugas sebagai DPRD. ${ }^{45}$ Selanjutnya melalui Maklumat Nomor 18 Tahun 1946, rakyat Yogyakarta diberi keleluasaan untuk ikut serta dalam pemerintahan, maka di desa-desa dibentuklah Dewan Perwakilan Rakyat Desa sebagai rekan kerja Lurah, yang mana hal ini menjadi wujud

\footnotetext{
43 Fajar Laksono, et al., "Status Keistimewaan Daerah Istimewa Yogyakarta dalam Bingkai Demokrasi Berdasarkan Undang-Undang Dasar 1945 (Studi Kasus Pengisian Jabatan Kepala Daerah dan Wakil Kepala Daerah)", Jurnal Konstitusi, Vol. 8, No. 6 (2011), hlm. 1070.

44 Ibid.

45 Hendra Kurniawan, "70 Tahun Amanat Keistimewaan", Kedaulatan Rakyat, 5 September 2015.
} 
demokrasi yang merupakan perubahan besar bagi sebuah entitas monarki. ${ }^{46}$

Kedudukan Yogyakarta sebagai daerah istimewa semakin diteguhkan dengan pengundangan Undang-Undang Nomor 3 Tahun 1950 tentang Pembentukan Daerah Istimewa Jogjakarta, yang di dalamnya secara tegas menyebut daerah yang meliputi daerah Kesultanan Jogjakarta dan daerah Paku Alaman ditetapkan menjadi Daerah Istimewa Yogyakarta, yang merupakan setingkat dengan Propinsi. ${ }^{47} \mathrm{Hal}$ tersebut semakin dikuatkan kembali dengan berlakunya Undang-Undang Nomor 13 Tahun 2012 tentang Keistimewaan Daerah Istimewa Yogyakarta (UU KDIY), yang memperjelas urusan keistimewaan yang menjadi penciri Yogyakarta sebagai daerah istimewa, selain juga tetap melaksanakan urusan pemerintahan daerah yang diberikan secara konkuren oleh UndangUndang Nomor 23 Tahun 2014 tentang Pemerintahan Daerah (UU Pemda). ${ }^{48}$ UU KDIY mendefinisikan keistimewaan sebagai keistimewaan kedudukan hukum yang dimiliki oleh DIY berdasarkan sejarah dan hak asal-usul menurut Undang-Undang Dasar Negara Republik Indonesia Tahun 1945 untuk mengatur dan mengurus kewenangan istimewa. ${ }^{49}$ Kewenangan dalam urusan Keistimewaan, meliputi: (a) tata cara pengisian jabatan, kedudukan, tugas, dan wewenang Gubernur dan Wakil Gubernur; (b) kelembagaan Pemerintah Daerah DIY; (c) kebudayaan; (d) pertanahan; dan (e) tata ruang. ${ }^{50}$

Selain menegaskan Keistimewaan DIY, UU KDIY juga memperkuat dan mempertegas kedudukan Kasultanan dan Kadipaten dalam kontes keistimewaan. UU KDIY menyebutkan Kasultanan Ngayogyakarta Hadiningrat (selanjutnya disebut Kasultanan) sebagai warisan budaya bangsa yang berlangsung secara turun-temurun dan dipimpin oleh Ngarsa Dalem Sampeyan Dalem Ingkang Sinuwun Kanjeng Sultan Hamengku Buwono Senapati Ing Ngalaga Ngabdurrahman Sayidin Panatagama Kalifatullah, selanjutnya disebut Sultan Hamengku Buwono. ${ }^{51}$ Sementara Kadipaten Pakualaman (selanjutnya disebut Kadipaten) sebagai warisan budaya bangsa yang berlangsung secara turun-temurun dan dipimpin oleh Kanjeng Gusti Pangeran Adipati Arya Paku Alam, selanjutnya disebut Adipati Paku Alam. ${ }^{52}$

Salah satu tujuan pengaturan keistimewaan DIY adalah melembagakan peran dan tanggung jawab Kasultanan dan Kadipaten dalam menjaga dan mengembangkan budaya Yogyakarta yang merupakan warisan budaya bangsa. ${ }^{53}$ Pelembagaan peran dan tanggung jawab Kasultanan dan Kadipaten tersebut diwujudkan melalui pemeliharaan, pendayagunaan, serta adat istiadat, dan tradisi luhur yang mengakar dalam masyarakat DIY. ${ }^{54}$ 
Keberadaan dan pelembagaan Kasultanan dan Kadipaten yang dikehendaki oleh UU KDIY ini semakin memperkuat dan mempertegas keistimewaan di Yogyakarta.

UU KDIY mengatur secara rinci dan lengkap apa saja peran Kasultanan dan Kadipaten dalam konteks Keistimewaan DIY. Pertama, dalam urusan keistimewaan tata cara pengisian jabatan Gubernur dan Wakil Gubernur. Kasultanan dan Kadipaten adalah institusi yang berhak mengajukan calon Gubernur dan calon Wakil Gubernur DIY. Kasultanan mengajukan Sultan Hamengku Buwono yang bertakhta sebagai calon Gubernur dan Kadipaten mengajukan Adipati Paku Alam yang bertakhta sebagai calon Wakil Gubernur kepada DPRD DIY. ${ }^{55}$ Surat Pencalonan untuk calon Gubernur yang diserahkan Kasultanan kepada DPRD DIY harus ditandatangani oleh Penghageng Kawedanan Hageng Panitrapura Kasultanan Ngayogyakarta Hadiningrat. ${ }^{56}$ Sementara surat pencalonan untuk calon Wakil Gubernur harus ditandatangani oleh Penghageng Kawedanan Hageng Kasentanan Kadipaten Pakualaman. ${ }^{57}$

Kasultanan dan Kadipaten juga berperan dalam hal Sultan Hamengku Buwono yang bertakhta tidak memenuhi syarat sebagai Gubernur dan Adipati Paku Alam yang bertakhta tidakmemenuhisyarat sebagaiWakil
Gubernur, maka Pemerintah mengangkat Penjabat Gubernur setelah mendapatkan pertimbangan dari Kasultanan dan Kadipaten sampai dilantiknya Sultan Hamengku Buwono yang bertakhta sebagai Gubernur dan/atau Adipati Paku Alam yang bertakhta sebagai Wakil Gubernur. ${ }^{58}$ Selain itu, Kasultanan juga berwenang memberitahukan kepada DPRD DIY mengenai pengukuhan Sultan Hamengku Buwono yang bertakhta sebagai Gubernur definitif dalam hal Gubernur yang sedang menjabat berhalangan tetap atau tidak memenuhi persyaratan lagi sebagai Gubernur atau diberhentikan sebelum berakhirnya masa jabatan Gubernur. ${ }^{59}$ Sementara, Kadipaten berwenang memberitahukan kepada DPRD DIY mengenai pengukuhan Adipati Paku Alam yang bertakhta sebagai Wakil Gubernur definitif, dalam hal Wakil Gubernur berhalangan tetap atau tidak memenuhi persyaratan lagi sebagai Wakil Gubernur atau diberhentikan sebelum berakhirnya masa jabatan Wakil Gubernur. ${ }^{60}$

Kedua, UU KDIY menyebutkan dalam urusan keistimewaan di bidang pertanahan, Kasultanan dan Kadipaten adalah badan hukum yang merupakan subjek hak yang mempunyai hak milik atas Tanah Kasultanan dan Tanah Kadipaten. ${ }^{61}$ Pengaturan tersebut mengartikan bahwa Kasultanan dan Kadipaten

55 Pasal 19 ayat (2) Undang-Undang Nomor 13 Tahun 2012 tentang Keistimewaan Daerah Istimewa Yogyakarta.

56 Pasal 19 ayat (3) huruf a Undang-Undang Nomor 13 Tahun 2012 tentang Keistimewaan Daerah Istimewa Yogyakarta.

57 Pasal 19 ayat (3) huruf b Undang-Undang Nomor 13 Tahun 2012 tentang Keistimewaan Daerah Istimewa Yogyakarta.

58 Pasal 26 ayat (7) Undang-Undang Nomor 13 Tahun 2012 tentang Keistimewaan Daerah Istimewa Yogyakarta.

59 Pasal 28 ayat (1) jo. ayat (5) huruf a Undang-Undang Nomor 13 Tahun 2012 tentang Keistimewaan Daerah Istimewa Yogyakarta.

60 Pasal 28 ayat (3) jo. ayat (5) huruf b Undang-Undang Nomor 13 Tahun 2012 tentang Keistimewaan Daerah Istimewa Yogyakarta.

61 Pasal 32 ayat (2) dan ayat (3) Undang-Undang Nomor 13 Tahun 2012 tentang Keistimewaan Daerah Istimewa Yogyakarta. 
sebagai badan hukum ini artinya ia sebagai institusi, bukan perseorangan yang merujuk pada individu Sultan Hamengku Buwono maupun Adipati Paku Alam. Tanah Kasultanan dan tanah Kadipaten tersebut meliputi tanah keprabon dan tanah bukan keprabon yang terdapat di seluruh kabupaten/kota dalam wilayah DIY. ${ }^{62}$ Oleh karena, Kasultanan dan Kadipaten adalah pemilik Tanah Kasultanan dan Tanah Kadipaten, maka mereka yang berwenang mengelola dan memanfaatkan tanah tersebut untuk sebesar-besarnya pengembangan kebudayaan, kepentingan sosial dan kesejahteraan masyarakat. Dalam hal pihak lain hendak mengelola dan memanfaatkan Tanah Kasultanan dan Tanah Kadipaten, maka harus mendapatkan izin persetujuan dari Kasultanan untuk tanah Kasultanan dan izin persetujuan dari Kadipaten untuk tanah Kadipaten. ${ }^{63}$ Ketiga, Kasultanan dan Kadipaten juga diberikan kewenangan oleh UU KDIY dalam hal urusan keistimewaan di bidang tata ruang, yakni Kasultanan dan Kadipaten berwenang menetapkan kerangka umum kebijakan tata ruang tanah Kasultanan dan tanah Kadipaten sesuai dengan Keistimewaan DIY dengan memperhatikan tata ruang nasional dan tata ruang DIY. ${ }^{64}$

UU KDIY secara jelas dan tegas mendudukkan posisi Kasultanan dan Kadipaten dalam konteks Keistimewaan DIY. UU KDIY menyebutkan bahwa kewenangan DIY sebagai daerah otonom mencakup kewenangan dalam urusan Pemerintahan
Daerah DIY sebagaimana dimaksud dalam UU Pemda dan juga urusan Keistimewaan yang ditetapkan oleh UU KDIY ada 5 (lima) kewenangan. UU KDIY memberikan beberapa kewenangan, setidaknya dalam tulisan ini dirangkum menjadi 3 (tiga) kewenangan kepada Kasultanan dan Kadipaten dalam penyelenggaraan urusan Keistimewaan, yakni (1) pengisian jabatan Gubernur dan Wakil Gubernur; (2) pertanahan; dan (3) tata ruang. Bahwa benar kalau yang menjadi pemimpin Kasultanan dan yang menjabat Gubernur DIY adalah orang yang sama yakni Sultan Hamengku Buwono, serta yang memimpin Kadipaten dan menjabat Wakil Gubernur DIY adalah Adipati Paku Alaman. Akan tetapi, UU KDIY ini secara jelas dan tegas mengatur mengenai mana kewenangan Gubernur dan Wakil Gubernur dalam menyelenggarakan urusan Pemerintahan Daerah DIY dan urusan Keistimewaan, dan mana kewenangan Kasultanan dan Kadipaten. Keduanya memiliki kamar dan porsi yang berbeda dan sudah diatur sesuai fungsinya. Kasultanan dan Kadipaten diberikan kewenangan oleh negara dalam menjalankan urusan Keistimewaan, ini juga merupakan wujud pengakuan dari negara atas terinkorporasinya institusi budaya (dalam hal ini Kasultanan dan Kadipaten) ke dalam Negara Kesatuan Republik Indonesia (NKRI). 


\section{Mendudukkan Kasultanan dan Kadipaten sebagai Subyek Hak Milik atas Tanah Kasultanan dan Tanah Kadipaten}

Spesifik terkait urusan keistimewaan di bidang pertanahan, UU KDIY mengatur Kasultanan dan Kadipaten sebagai badan hukum dan merupakan subjek hak yang mempunyai hak milik atas tanah. ${ }^{65}$ Pengaturan tersebut di satu sisi memberikan kepastian hukum terhadap hak milik atas tanah Kasultanan atau Kadipaten, namun di sisi yang lain menimbulkan perdebatan akademik, khususnya terkait pemaknaan beberapa hal berikut: (a) penetapan Kasultanan dan Kadipaten sebagai badan hukum menimbulkan kegamangan dalam mengidentifikasi apakah dapat dikualifikasikan sebagai badan hukum publik atau privat. Bagaimana konsekuensi yang melekat dari disandangnya kualifikasi badan hukum publik atau privat tersebut? (b) penetapan Kasultanan dan Kadipaten sebagai subyek hak pemegang hak milik atas tanah menimbulkan pertanyaan, hak milik atas tanah seperti apa yang dimaksud dalam UU KDIY? Apakah hak milik atas tanah sebagaimana yang diatur dalam Pasal 20 Undang-Undang Nomor 5 Tahun 1960 tentang Peraturan Dasar Pokok-Pokok Agraria (UUPA)? Hal tersebut perlu kiranya dielaborasi terlebih dahulu, sehingga dapat memberikan pemahaman yang utuh mengenai kedudukan Kasultanan dan Kadipaten sebagai badan hukum dan merupakan subjek hak yang mempunyai hak milik atas tanah Kasultanan atau Kadipaten.
Pertama, penetapan Kasultanan dan Kadipaten sebagai badan hukum. Pengaturan Kasultanan dan Kadipaten sebagai badan hukum dalam UU KDIY yang dapat menjadi subyek hukum hak milik atas tanah Kasultanan dan Kadipaten menimbulkan pertanyaan lebih lanjut, apakah status badan hukum Kasultanan dan Kadipaten merupakan badan hukum publik atau badan hukum privat sebagaimana dikenal dalam hukum positif di Indonesia? Ataukah Kasultanan dan Kadipaten dapat dikualifikasikan sebagai tipologi badan hukum baru yang belum dikenal dalam hukum positif Indonesia?

Khusus dalam konteks badan hukum yang dapat menjadi subyek hak berupa hak milik atas tanah, Pasal 21 ayat (2) UUPA mengatur bahwa, "Oleh Pemerintah ditetapkan badanbadan hukum yang dapat mempunyai hak milik dan syarat-syaratnya"66, yang mana hal tersebut ditindaklanjuti dengan dibentuknya Peraturan Pemerintah Nomor 38 Tahun 1963 tentang Penunjukan Badan-Badan Hukum yang Dapat Mempunyai Hak Milik Atas Tanah (PP 38/1963). Dalam Pasal 1 PP 38/1963 diatur bahwa: 67

Badan-badan hukum yang disebut di bawah ini dapat mempunyai hak milik atas tanah, masing-masing dengan pembatasan yang disebutkan pada Pasal-Pasal 2, 3, dan 4 Peraturan ini:

a. Bank-bank yang didirikan oleh Negara (selanjutnya disebut Bank Negara);

b. Perkumpulan-perkumpulan Koperasi Pertanian yang didirikan berdasar atas Undang-Undang Nomor 79 Tahun 1958

\footnotetext{
65 Pasal 32 ayat (1), ayat (2), dan ayat (3) Undang-Undang Nomor 13 Tahun 2012 tentang Keistimewaan Daerah Istimewa Yogyakarta.

66 Pasal 21 ayat (2) Undang-Undang Nomor 5 Tahun 1960 tentang Peraturan Dasar Pokok-Pokok Agraria.

67 Pasal 1 Peraturan Pemerintah Nomor 38 Tahun 1963 tentang Penunjukan Badan-Badan Hukum yang Dapat Mempunyai Hak Milik Atas Tanah.
} 
(Lembaran Negara Tahun 1958 Nomor 139);

c. Badan-badan keagamaan, yang ditunjuk oleh Menteri Pertanian/Agraria, setelah mendengar Menteri Agama;

d. Badan-badan sosial, yang ditunjuk oleh Menteri Pertanian/Agraria, setelah mendengar Menteri Kesejahteraan Sosial.

Berdasarkan pengaturan tersebut, dapatkah Kasultanan dan Kadipaten dikualifikasikan sebagai salah satu badan hukum yang diatur dalam PP 38/1963? Secara sederhana dapat dijawab bahwa Kasultanan dan Kadipaten tidak dapat dikualifikasikan sebagai salah satu badan hukum menurut PP 38/1963. Lantas, apakah dengan tidak masuknya kualifikasi Kasultanan dan Kadipaten dalam badan hukum menurut PP 38/1963 mutatis mutandis membuat Kasultanan dan Kadipaten tidak dapat mempunyai hak milik atas tanah menurut Pasal 21 ayat (2) UUPA? Apakah penetapan badan hukum oleh Pemerintah dan syarat-syaratnya hanya dapat dijabarkan oleh PP 38/1963, sehingga entitas lain yang tidak disebut oleh PP 38/1963 mutatis mutandis tidak dapat mempunyai hak milik atas tanah?

Diperlukan pemahaman ilmu perundangundangan yang lebih jernih untuk memaknai ketentuan yang tertuang dalam Pasal 21 ayat (2) UUPA. Pemahaman Pertama, Pemerintah berwenang menentukan badan hukum yang ditetapkan dapat mempunyai hak milik atas tanah. Pemahaman ini dapat ditemukan dengan mencermati Penjelasan Umum Nomor II angka 5 alinea kedua UUPA, yang menjelaskan: ${ }^{68}$
Meskipun pada dasarnya badan-badan hukum tidak dapat mempunyai hak milik atas tanah, tetapimengingat akan keperluan masyarakat [...] maka diadakanlah suatu "escape-clause" yang memungkinkan badan-badan hukum tertentu mempunyai hak milik. Dengan adanya "escape-clause" ini maka cukuplah nanti bila ada keperluan akan hak milik bagi sesuatu atau sesuatu macam badan hukum diberikan dispensasi oleh Pemerintah, dengan jalan menunjuk badan hukum tersebut sebagai badan hukum yang dapat mempunyai hak milik atas tanah (pasal 21 ayat 2). [...].

Mendasarkan pada penjelasan di atas, maka dapat disimpulkan bahwa Pemerintah memiliki keleluasaan untuk menentukan entitas mana yang ditetapkan sebagai badan hukum yang dapat mempunyai hak milik atas tanah. Keleluasaan yang diberikan oleh UUPA tidak bersifat einmaligh melainkan dauerhaftig, yang berarti norma dalam Pasal 21 ayat (2) UUPA berlaku terus menerus sampai norma tersebut dibatalkan. Dengan demikian, keluarnya PP 38/1963 tidak dapat menghentikan keberlakuan Pasal 21 ayat (2) UUPA yang membuat Pemerintah tidak lagi bisa menetapkan entitas lain sebagai badan hukum yang mempunyai hak milik atas tanah. Pemerintah tetap dapat menentukan entitas lain sebagai badan hukum yang dapat mempunyai hak milik atas tanah, selain yang sudah diatur dalam PP 38/1963.

Adapun wadah pengaturan Pemerintah dalam melaksanakan ketentuan Pasal 21 ayat (2) UUPA pun tidak tunggal. Betul memang menurut Pasal 5 ayat (2) Undang-Undang Dasar Negara Republik Indonesia Tahun 1945 (UUD NRI Tahun 1945) disebutkan bahwa

68 Penjelasan Umum Nomor II angka 5 Undang-Undang Nomor 5 Tahun 1960 tentang Peraturan Dasar PokokPokok Agraria. 
Presiden membentuk Peraturan Pemerintah untuk melaksanakan Undang-Undang sebagaimana mestinya, ${ }^{69}$ namun Pemerintah, dalam hal ini Presiden, dapat pula membuat pengaturan pada level Undang-Undang untuk melaksanakan perintah Undang-Undang ${ }^{70}$. Dengan demikian, dapat saja Pemerintah mengatur mengenai penetapan entitas badan hukum yang dapat mempunyai hak milik atas tanah dalam pengaturan pada level UU, mengingat pengaturan pada level UU juga memerlukan kesepahaman kehendak mengatur antara Presiden sebagai pemegang kekuasaan pemerintahan dan DPR sebagai pemegang kekuasaan pembentuk UU.

Mendasarkan pada pemahaman di atas, maka Kasultanan dan Kadipaten dapat saja ditetapkan sebagai entitas badan hukum yang dapat mempunyai hak milik atas tanah menurut UU KDIY. Penetapan Kasultanan dan Kadipaten sebagai badan hukum yang dapat mempunyai hak milik atas tanah dalam UU KDIY harus dipahami dan dimaknai sebagai wujud pelaksanaan Pasal 21 ayat (2) UUPA, berupa perwujudan kewenangan Pemerintah dalam menetapkan badan hukum yang dapat mempunyai hak milik atas tanah, dengan adanya kesepahaman kehendak dengan DPR untuk menuangkannya dalam UU KDIY.

Pemahaman Kedua, jenis entitas yang dapat ditetapkan sebagai badan hukum yang mempunyai hak milik atas tanah tidak enumeratif. Berbekal pemahaman pada uraian sebelumnya, maka dapat ditarik pemahaman bahwa jenis entitas yang dapat ditetapkan sebagai badan hukum yang mempunyai hak milik atas tanah tidak disebutkan secara definitif dan terbatas hanya pada entitas yang ada dalam UUPA, seperti badan hukum yang bergerak dalam lapangan sosial dan keagamaan sebagaimana ditunjuk dalam Pasal 49 UUPA sebagai badan hukum yang dapat mempunyai hak milik atas tanah.

Pemahaman ini sejalan dengan pengaturan dalam Pasal 1653 Kitab UndangUndang Hukum Perdata (KUHPerdata) yang menyatakan bahwa: ${ }^{71}$

Selain perseroan perdata sejati,
perhimpunan orang-orang sebagai badan
hukum juga diakui undang-undang, entah
badan hukum itu diadakan oleh kekuasaan
umum atau diakuinya sebagai demikian,
entah pula badan hukum itu diterima
sebagai yang diperkenankan atau telah
didirikan untuk suatu maksud tertentu
yang tidak bertentangan dengan undang-
undang atau kesusilaan.

Dengan demikian, KUHPerdata mengelompokkan badan hukum menjadi: (a) perseroan perdata sejati; dan (b) perhimpunan orang-orang sebagai badan hukum. Mohammad Fajrul Falaakh dalam keterangan ahli pada pengujian UU Nomor 12 Tahun 2012 tentang Pendidikan Tinggi (UU Dikti) terhadap UUD NRI Tahun 1945, dalam perkara Nomor 33/PUU-XI/2013, menyatakan bahwa Pasal 1653 KUHPerdata mengenalkan empat jenis zedelijke lichaamen: (a) badan hukum yang didirikan oleh negara, (b) diakui oleh negara, (c) diperkenankan oleh negara, dan (d) badan hukum yang didirikan untuk maksud atau tujuan tertentu. ${ }^{72}$

69 Pasal 5 ayat (2) Undang-Undang Dasar Negara Republik Indonesia Tahun 1945.

70 Pasal 10 ayat (1) Undang-Undang Nomor 12 Tahun 2011 tentang Pembentukan Peraturan Perundang-undangan.

71 Pasal 1653 Kitab Undang-Undang Hukum Perdata.

72 Putusan Mahkamah Konstitusi Nomor 33/PUU-XI/2013 perihal Pengujian Undang-Undang Nomor 12 Tahun 2012 tentang Pendidikan Tinggi terhadap Undang-Undang Dasar Negara Republik Indonesia Tahun 1945, hlm. 154. 
Berdasarkan hal tersebut, Kasultanan dan Kadipaten dapat dikualifikasikan merupakan badan hukum yang masuk dalam kriteria huruf $b$, yakni badan hukum yang diakui oleh negara. Kasultanan dan Kadipaten tidak masuk dalam kategori huruf a dan d karena Kasultanan dan Kadipaten tidak dibentuk/ didirikan oleh negara atau dibentuk/ didirikan untuk maksud atau tujuan tertentu. Kasultanan dan Kadipaten bukan pula badan hukum yang masuk dalam kategori huruf c karena Kasultanan dan Kadipaten bukan badan hukum yang mendapatkan perkenan dari negara seperti badan keagamaan atau badan sosial.

Berdasarkan pada pemahaman tersebut, Kasultanan dan Kadipaten merupakan badan hukum dalam kategori badan hukum yang diakui oleh negara, karena memang Kasultanan dan Kadipaten sudah ada sebelum Republik Indonesia merdeka, sehingga berlaku prinsip rekognisi terhadap keberadaan Kasultanan dan Kadipaten. Oleh karena itu, Kasultanan dan Kadipaten dapat dikualifikasikan sebagai badan hukum. Namun, badan hukum apakah Kasultanan dan Kadipaten? Badan hukum publik atau badan hukum privat? Untuk menjawab pertanyaan tersebut, harus dipahami bahwa dalam perkembangan hukum positif Indonesia telah terjadi perkembangan mengenai kelembagaan badan hukum. Merujuk pada Putusan Mahkamah Konstitusi (MK) Nomor 33/PUU-XI/2013 misalnya, MK mengakui konstitusionalitas Perguruan Tinggi Negeri badan hukum (PTNbh) sebagai jenis badan hukum khusus yang dikenalkan oleh
UU Dikti. PTNbh merupakan contoh nyata badan hukum yang tidak dapat serta merta dikualifikasikan sebagai badan hukum publik atau privat, karena secara bersamaan fungsi publik dan privat melekat dan menjadi penciri badan hukum khusus yang bernama PTNbh.

Mendasarkan pada pemahaman mengenai badan hukum jenis baru tersebut, maka Kasultanan dan Kadipaten dapat dilepaskan dari batasan-batas badan hukum publik atau badan hukum privat. Kasultanan dan Kadipaten adalah badan hukum khusus yang dikenalkan oleh UU KDIY, dengan karakteristik mempunyai hak milik atas tanah Kasultanan dan Kadipaten. Pada dasarnya, perpaduan antara aspek publik dan privat yang melekat secara inheren juga sejalan dengan konsep dalam hukum adat. Aspek publik dalam hukum adat tampak dalam kewenangan masyarakat hukum adat mengatur: (a) tanah/wilayah sebagai ruang hidupnya terkait dengan pemanfaatannya termasuk pemeliharaannya; (b) hubungan hukum antara masyarakat hukum adat dengan tanahnya; dan (3) perbuatan hukum terkait dengan tanah masyarakat hukum adat. ${ }^{73}$ Sementara itu, aspek privat dalam hukum adat adalah kewenangan masyarakat hukum adat menggunakan tanah secara bersamasama. $^{74}$

Kedua, penetapan Kasultanan dan Kadipaten sebagai subyek hak pemegang hak milikatastanah. Hakmilikyang dimaksud dalam UU KDIY merupakan hak milik sebagaimana diatur bahwa, "Hak milik adalah hak turun temurun, terkuat dan terpenuh yang dapat

73 Maria S.W. Sumardjono, Regulasi Pertanahan dan Semangat Keadilan Agraria (Yogyakarta: STPN Press, 2018), hlm. 37.

74 Ibid. 
dipunyai orang atas tanah, dengan mengingat ketentuan dalam Pasal 6"75, dan "Hak milik dapat beralih dan dialihkan kepada pihak lain"76. Berdasarkan pengaturan tersebut, hak milik mempunyai karakteristik: (a) hak turun temurun; (b) terkuat dan terpenuh; dan (c) dapat beralih dan dialihkan kepada pihak lain. Namun dalam konteks, hak milik atas tanah Kasultanan dan Kadipaten, terdapat pengecualian karena tanah Kasultanan dan Kadipaten tidak dapat beralih dan dialihkan. Hal ini menjadi lex specialis dari konsep hak milik atas tanah dalam UUPA sebab apabila hak milik atas tanah Kasultanan dan Kadipaten beralih atau dialihkan, maka mutatis mutandis Yogyakarta akan kehilangan keistimewaannya, karena pertanahan adalah salah satu urusan keistimewaan dari Yogyakarta yang diatur dalam UU KDIY.

\section{Penutup}

Berdasarkan analisis dan uraian di atas, dapat disimpulkan sebagai berikut: Pertama, konstruksi hukum hak milik atas tanah dalam sistem hukum Indonesia adalah hak turun temurun, terkuat dan terpenuh yang dapat dipunyai orang atas tanah. Hak milik dapat beralih dan dialihkan kepada pihak lain. Subjek penyandang hak milik atas tanah antara lain: (1) WNI; dan (2) badan-badan hukum yang ditetapkan oleh Pemerintah. Pada dasarnya badan-badan hukum tidak dapat mempunyai hak milik, namun mengingat akan keperluan masyarakat yang sangat erat hubungannya dengan paham keagamaan, sosial dan hubungan perekonomian, maka diadakanlah suatu "escape-clause" yang memungkinkan badan-badan hukum tertentu mempunyai hak milik. Dengan adanya "escape-clause" ini maka cukuplah nanti bila ada keperluan akan hak milik bagi sesuatu atau macam badan hukum diberikan dispensasi oleh Pemerintah, dengan jalan menunjuk badan hukum tersebut sebagai badan-badan hukum yang dapat mempunyai hak milik atas tanah.

Kedua, kedudukan hukum Kasultanan dan Kadipaten dalam konteks Keistimewaan Yogyakarta menurut UU KDIY adalah Kasultanan dan Kadipaten merupakan warisan budaya bangsa yang berlangsung secara turun-temurun dan diberikan kewenangan oleh UU KDIY dalam menjalankan urusan keistimewaan. Kasultanan dan Kadipaten diberikan kewenangan oleh UU KDIY dalam 3 (tiga) bidang urusan Keistimewaan, yakni tata cara pengisian jabatan Gubernur dan Wakil Gubernur DIY, Pertanahan, dan Tata Ruang. Walaupun yang menjadi pemimpin Kasultanan dan yang menjabat Gubernur DIY adalah orang yang sama, yakni Sultan Hamengku Buwono, serta yang memimpin Kadipaten dan menjabat Wakil Gubernur DIY adalah Adipati Paku Alaman, namun UU KDIY secara jelas dan tegas mengatur mengenai mana yang menjadi kewenangan Gubernur dan Wakil Gubernur dalam menyelenggarakan urusan Pemerintahan Daerah DIY dan urusan keistimewaan, dan mana kewenangan Kasultanan dan Kadipaten dalam menjalankan urusan keistimewaan. Keduanya memiliki kamar dan porsi yang berbeda dan sudah diatur sesuai fungsinya. Kasultanan dan Kadipaten diberikan kewenangan oleh negara dalam menjalankan urusan keistimewaan, ini

75 Pasal 20 ayat (1) Undang-Undang Nomor 5 Tahun 1960 tentang Peraturan Dasar Pokok-Pokok Agraria.

76 Pasal 20 ayat (2) Undang-Undang Nomor 5 Tahun 1960 tentang Peraturan Dasar Pokok-Pokok Agraria. 
juga merupakan wujud pengakuan dari negara atas terinkorporasinya institusi budaya (dalam hal ini Kasultanan dan Kadipaten) ke dalam Negara Kesatuan Republik Indonesia (NKRI).

Ketiga, Kasultanan dan Kadipaten merupakan badan hukum dalam kategori badan hukum yang diakui oleh negara, karena memang Kasultanan dan Kadipaten sudah ada sebelum Republik Indonesia merdeka, sehingga berlaku prinsip rekognisi terhadap keberadaan Kasultanan dan Kadipaten. Kasultanan dan Kadipaten dapat dilepaskan dari batasan-batas badan hukum publik atau badan hukum privat. Karena Kasultanan dan Kadipaten merupakan badan hukum khusus yang dikenalkan oleh UU KDIY, dengan karakteristik mempunyai hak milik atas tanah Kasultanan dan Kadipaten. Pada dasarnya, perpaduan antara aspek publik dan privat yang melekat secara inheren juga sejalan dengan konsep dalam hukum adat.

\section{Daftar Pustaka}

\section{Buku}

Rozaki, Abdur, et al., Membongkar Mitos Keistimewaan Yogyakarta (Yogyakarta: IRE Press, 2003).

Soekanto, Soedjono dan Sri Mamudji, Penelitian Hukum Normatif: Suatu Tinjauan Singkat (Jakarta: Raja Grafindo Persada, 1994).

Soekanto, Soerdjono, Pengantar Penelitian Hukum (Jakarta: UI Press, 1986).

Sumardjono, Maria S.W., Regulasi Pertanahan dan Semangat Keadilan Agraria (Yogyakarta: STPN Press, 2018).

Anggara, Daerah Istimewa dalam Sistem Ketatanegaraan Indonesia: Dinamika Sejarah dan Perkembangannya (Jakarta: Creative Commons Attribution 4.0 International License, 2019).

\section{Makalah/Jurnal/ Artikel/Hasil Seminar}

Hendra Kurniawan, "70 Tahun Amanat Keistimewaan", Kedaulatan Rakyat, 5 September 2015.

Laksono, Fajar, et al., "Status Keistimewaan Daerah Istimewa Yogyakarta dalam Bingkai Demokrasi Berdasarkan Undang-Undang Dasar 1945 (Studi Kasus Pengisian Jabatan Kepala Daerah dan Wakil Kepala Daerah)", Jurnal Konstitusi, Vol. 8, No. 6 (2011).

\section{Peraturan}

Undang-Undang Dasar Negara Republik Indonesia Tahun 1945.

Kitab Undang-Undang Hukum Perdata.

Undang-Undang Nomor 5 Tahun 1960 tentang Peraturan Dasar Pokok-Pokok Agraria.

Undang-Undang Nomor 3 Tahun 1950 tentang Pembentukan Daerah Istimewa Jogjakarta.

Undang-Undang Nomor 12 Tahun 2011 tentang Pembentukan Peraturan Perundangundangan.

Undang-Undang Nomor 13 Tahun 2012 tentang Keistimewaan Daerah Istimewa Yogyakarta.

Peraturan Pemerintah Nomor 38 Tahun 1963 tentang Penunjukan Badan-Badan Hukum yang Dapat Mempunyai Hak Milik Atas Tanah.

Peraturan Pemerintah Nomor 24 Tahun 1997 tentang Pendaftaran Tanah. Peraturan Pemerintah Nomor 40 Tahun 1996 tentang Hak Guna Usaha, Hak Guna Bangunan, dan Hak Pakai.

\section{Putusan Pengadilan}

Putusan Mahkamah Konstitusi Nomor 33/PUU$\mathrm{XI} / 2013$ perihal Pengujian Undang-Undang Nomor 12 Tahun 2012 tentang Pendidikan Tinggi terhadap Undang-Undang Dasar Negara Republik Indonesia Tahun 1945.

\section{Dokumen Lainnya}

Piagam Penetapan Sultan Hamengku Buwono IX dan Paku Alam VIII dari Presiden Republik Indonesia.

Berita Republik Indonesia Tahun II Nomor 4-5. Berita Republik Indonesia Tahun II Nomor 6. 